1956 his academic distinction was already apparent by the award of the university's

Stuart Prize and Joseph Pullar scholarship.

Gene has been a UK citizen since 1966. His basic and higher training in psychiatry was at the Maudsley Hospital where his contemporaries included Loic Hemsi and Trevor Silverstone. He then spent 5 years at Yale University, 1966-1971, where he was Co-Director and later Director of the Depression Research Unit, working closely with Gerald Klerman and Myrna Weissman and carrying out groundbreaking research on the classification of depression and on the role of life events in its aetiology.

On his return to the UK Gene was appointed consultant and senior lecturer at St George's Hospital. In 1975 he was promoted to reader and in 1977 to a personal chair. He was appointed to succeed Sir Martin Roth as Professor of Psychiatry of the University of Cambridge in 1985. He has written or edited eight academic psychiatric texts and over 300 scientific papers. Much of his recent work has been on the biology of depression and on its treatment in both hospital and primary care settings. He is regarded as one of the leading world authorities both on depressive illness and on puerperal psychiatric disorders.

When I told Gene I was going to be presenting him for our Honorary Fellowship, he asked me not to say he was (and I quote) a "grumpy old bugger who when you worked with him was perpetually away somewhere else". Nothing could be further from the truth. He was and remains an inspiring teacher who was trainer and mentor to a clutch of future professors of psychiatry including Thomas Barnes, Ted Dinan and myself. He was also impressively always there - to the extent we juniors had our work cut out hiding our plans on how to manage his patients from him lest he interfered. I remember visiting him in hospital after he'd suffered a back injury shortly after I started working with him. He was flat in bed, in severe pain but with a foot high pile of papers and a dictaphone and in full work mode.

Gene is also a very distinguished journal editor. With George Winokur he founded Journal of Affective Disorders and grew it into a major and highly cited journal. He then went on to succeed Michael Shepherd as sole Editor-in-Chief of Psychological Medicine, which under his stewardship has increased its range while remaining near the top of the premier league of psychiatric journals.

Several organisations have gone before us in recognising Gene's exceptional distinction, particularly in psychopharmacology. He is the current President of Collegium Internationale Neuropsychopharmacologium (CINP), was a Founder Fellow, Academy of Medical Sciences and earlier this year was recipient of the European College of Neuropsychopharmacology (ECNP) Lilly award for clinical neuroscience.

Gene Paykel has made a major and sustained contribution to the life of our College at the very highest level. Among other things he was Chairman of the Scientific Advisory Committee of the Defeat Depression Campaign, of the Social and Community Psychiatry Section and of the Joint Committee on Higher Psychiatric Training. Between 1994 and 1996 he was Vice-President of the College.

I am proud to be able to Present Professor Eugene Paykel for the award of our College's highest accolade, the Honorary Fellowship. Few people have contributed as much to our College, and to psychiatry.

\section{Professor Roy Porter} (introduced by Dr D. Bhugra)

It will not be an exaggeration to say that Professor Roy Sidney Porter is the most distinguished and outstanding social and medical historian of his generation. Professor Porter graduated from Christ's College Cambridge with first class honours with distinctions in the history tripos. Two years later he was appointed Research Fellow of Christ's College, Cambridge. In 1972 he was appointed Fellow and Director of Studies in History, Churchill College, Cambridge. He was awarded his PhD from Cambridge in 1974 and in the same year was appointed Assistant Lecturer in European History. He was appointed Lecturer in European History in 1977 and the same year he was appointed Dean of Churchill College, Cambridge. In 1979 he was appointed Senior Lecturer at the Wellcome Institute for the History of Medicine, London. American universities queued to honour him and offer him visiting professorship and fellow status. In 1991 he was appointed Reader and in 1993 appointed Professor. He is currently Professor in the Social History of Medicine at the Wellcome Institute for the History of Medicine. He has been a Visiting Fellow at the University of California at Los Angeles, Stanford University and Princeton University. He was elected Fellow of the British Academy and the New York Academy and was given the Honorary Fellowship of the Royal College of Physicians. With Dr German Berrios he founded the journal History of Psychiatry, which is going from strength to strength.

He has authored, co-authored, edited or co-edited more than 100 books and 350 academic papers. Of these, mention must be made of Mind Forg'd Manacles, which was awarded the Leo Gezshey Prize of the American Historical Association. His volumes The Faber Book of Madness, The History of Bethlem, Cultures of Psychiatry, London: A Social History and Enlightenment have already become classics. The volume on enlightenment has already gone into a second edition and is now being made into a film. He has made significant contributions to our understanding of the social history of stigma, mental illness, psychiatric institutions and alienists.

His teaching skills keep the students undergraduate and postgraduate spellbound. As this is the Royal College of Psychiatrists' meeting it is time for a confession. When I had the privilege of sitting through his lectures on history of mental illness, history came alive. He has the ability of presenting findings and observations as a painter would on a canvas. He has made significant contributions to our understanding of the social history of medicine in general and psychiatry in particular. It is a great source of pleasure and pride for the profession to present Professor Roy Porter for the Honorary Fellowship of the Royal College of Psychiatrists.

\title{
Winter Business Meeting
}

4.30-5.00p.m. on 5 February 2002, to be held at the Royal College of Psychiatrists following the meeting of Council. Chaired by the President, Professor John Cox.

\section{Agenda}

(1) To approve the Minutes of the previous Winter Business Meeting held at the Royal College of Psychiatrists on 6 February 2001

\section{(2) Obituary}

(3) Election of Honorary Fellows

\section{Professor David A. Alexander}

Throughout his career as a clinical psychologist, Professor Alexander has always believed in the mutual value of collaborative work between psychologists and psychiatrists, and between psychologists and other medical disciplines. He has worked in the University of Aberdeen's Department of Mental Health since 1971, acquiring a personal Chair in 1994. It is difficult to overestimate his contribution to undergraduate education in psychiatry, and through the Aberdeen Postgraduate Training Scheme in Psychiatry he has also provided excellent clinical and research supervision, and acted as advocate for many young psychiatrists. In 1998, Professor Alexander spearheaded the 
7?

columns response of psychiatric services to the Piper Alpha Disaster in the North Sea; since then his clinical and research work has focused to a great extent upon the care of victims of various kinds of trauma. He became Director of Scotland's first Centre for Trauma Research, which was opened by Terry Waite in 1999. Professor Alexander has also established himself internationally as a renowned clinical and academic expert in the field of trauma. He has lectured in 17 countries and has the almost unique distinction of acting as Visiting Lecturer to the FBI Academy in the USA. Professor Alexander also visited Nairobi in 1998, following the bombing of the American Embassy when 253 people were killed; his expert and humane contribution proved to be immensely valuable to both victims and professional colleagues.

\section{Professor Sir David Goldberg}

Professor Goldberg has had a long and distinguished career in psychiatry, including being Professor of Psychiatry and Director of Research and Development at the Maudsley Hospital, London. A Gaskell Gold Medallist, he has maintained a close relationship with the College over many years. His numerous College roles include being Secretary of the Research Committee; a member of the Court of Electors; Chairman of the General Psychiatry Specialist Advisory Sub-Committee; Regional Adviser for Manchester and, between 2000 and 2001, Director of the College Research Unit. Professor Goldberg has also been a member of the DHSS Research Liaison Group, the Neurosciences Board, Medical Research Council and Wellcome Trust, and the Department of Health's Central Research and Development Committee (CRDC). He was Chairman of the CRDC's Mental Illness Steering Group and London Commissioner on Mental Illness (King's Fund). He was also on the Education Committee of the World Psychiatric Association (WPA) and has undertaken extensive work for the World Health Organization (WHO). In 1998, he received the Adolf Meyer Award of the American Psychiatric Association. In Manchester, he established undergraduate medical education based on teaching interview techniques and seeing psychiatry as an integral part of medical practice, set up the research option for all undergraduates and the first dedicated training scheme for overseas medical graduates. Professor Goldberg was Founding Director of the Mental Illness Research Unit, designed and developed the General Health Questionnaire and initiated seven other commonly used research assessments. As a result of Professor Goldberg's efforts, the Maudsley Discussion Papers now bring controversial issues affecting the care of mental disorders to the attention of politicians, NHS managers and public servants. He has tirelessly campaigned for more resources for community mental health teams with successive ministers, and was successful in persuading the Department of Health to increase the resource allocation to deprived inner-city areas.

\section{Professor Kevin Gournay, CBE}

Professor Gournay is an outstanding academic, clinician and teacher and has made a major contribution to the field of nursing and to multi-professional mental health developments both nationally and internationally. At the Institute of Psychiatry, he is currently Professor of Psychiatric Nursing and Deputy Head of the Health Services Research Department. He holds qualifications in nursing, psychology, training in behavioural psychotherapy, and was also awarded a CBE in the New Year Honours list 1998 for services to psychiatric nursing, research and education. In addition, he is an elected Fellow of the Academy of Medical Sciences and an elected Fellow of the Royal College of Nursing. Within his academic role he has produced outstanding results to develop one of the most successful nursing research teams in Britain. Alongside this he has numerous external affiliations and responsibilities, including acting as an advisor to ministers on a regular basis and preparing advice to the House of Commons Select Committee Inquiries. He is a Visiting Professor to the University of Wollongong and a member of the task force for the training initiative to the Romanian mental health services. His publications are both prolific and consistent in showing his dedication to quality and relevance to clinical care. $\mathrm{He}$ has produced two single-author books, three edited books and two monographs and is the author of over 80 conference papers presented around the world, as well as more than 130 papers in peerreviewed journals and numerous book chapters.

\section{Professor Assen V. Jablensky}

Professor Jablensky originally trained in medicine and psychiatry in his native Bulgaria and subsequently worked as a registrar at the Maudsley for 2 years during the late 1960s. He then spent 14 years on the staff of the $\mathrm{WHO}$, where he was successively principal investigator of each of the WHO's three great international studies - the International Pilot Study of Schizophrenia, Determinants of Outcome of Severe Mental Disorders and the Collaborative Study on Depressive
Disorders in Different Cultures. It was also he who laid the foundations of the ICD-10 Classification of Mental and Behavioural Disorders. Partly for these reasons, he is now one of the best known and highly respected psychiatric researchers in the world. Since moving to Western Australia in 1993, he has built up an impressive research-based department and mounted a series of innovative studies of the epidemiology of psychosis in Australia. His high international reputation is illustrated not just by the international prizes he has been awarded but also by the posts to which he has been appointed - membership of the Executive Board of the WHO, Co-Chair of a US National Academy of Sciences Committee and membership of the WPA's ethics committee. Professor Jablensky has maintained many links with the UK since he worked here in the 1960s. He is a Fellow of the College and a member of the International Advisory Boards of both Psychological Medicine and the British Journal of Psychiatry.

\section{Dr Rosemary MacDonald}

Dr MacDonald retired in October 2001 after 34 years of service to the NHS. She has enjoyed a distinguished career, where her early reputation was based on original research into pain relief for obstetric anaesthesia. She pioneered the introduction of new clinical techniques as the first Clinical Director of Anaesthetic Services at St James' University Hospital, one of the largest teaching hospitals in Europe. Her subsequent career has become particularly associated with her contributions to postgraduate education and training, first as Clinical Sub-Dean of the Medical School in Leeds and then as Dean of Postgraduate Medical Education to the Yorkshire Deanery from 1993 until the present. She has encouraged the advancement of psychiatric training in the region by her support in many areas, including: the development of the first specialist postgraduate medical education centre specifically for trainees in psychiatry; the continuance of the Masters training course at Leeds University, assisting in its progressive quality improvements; providing new funding for training courses; and the investments required to develop raining following recommendations from educational inspection visits. Since 1999, her contributions as Lead Dean in Psychiatry will be familiar to many in the College, during which time she has been active in supporting workforce planning, rationalising national training numbers, encouraging recruitment and retention and generally promoting training and development for the speciality. 